\title{
Social innovation: A decolonial interpretive framework in Colombian rurality
}

Jhusty Meliza Moreno Henao'

\begin{abstract}
This article weaves together a critique and explanation, from a decolonial interpretive framework, of how and why rural communities in the Colombian countryside have persisted despite the imposition of the colonizing model and the breakdown of traditional forms of peasant agriculture trapped by modern Western rationality, which brought with it the hegemonic discourse of development in the $20^{\text {th }}$ century and innovation as a fundamental element in linking peasant production to the capitalist economic system. This paper arises from the essence of Colombian peasant communities, which despite the imposition of 'modernization' based on scientific epistemology and economic growth have resisted and persisted through social movements, selforganizing processes and spaces for the reorientation of development, as well as the political construction of the thinking-feeling of the territories that has triggered social processes of the other innovation, the participatory action to provide solutions to technological, economic and social issues of the communities. Finally, it reflects on the social process of innovation in its decolonial, ontological and territorial character, as a commitment to redefine good living, territorial life projects and local economies.
\end{abstract}

Keywords: Innovation, development, social innovation, decolonial thinking.

\section{La innovación social: Un marco interpretativo decolonial en la ruralidad colombiana}

\section{Resumen}

El presente artículo teje a través de una crítica y explicación, desde un marco interpretativo decolonial, cómo y porqué las comunidades campesinas en el campo colombiano han persistido a pesar de la imposición del modelo colonizador. La ruptura de las formas tradicionales de la agricultura campesina atrapada por la racionalidad moderna occidental, que trajo consigo el discurso hegemónico del desarrollo en el siglo XX y la innovación como un elemento fundamental para vincular la producción campesina al sistema económico capitalista, se plantea desde la esencia de las comunidades campesinas colombianas, que a pesar de la imposición de la 'modernización' basada en la epistemología científica y el crecimiento económico, han resistido y persistido a través de movimientos sociales, procesos autoorganizativos y espacios para la reorientación del desarrollo, así como la construcción política del sentipensar de los territorios que ha desencadenado en procesos sociales de la otra innovación, la acción participativa para dar soluciones a emergencias tecnológicas, económicas y sociales de las comunidades. Se reflexiona sobre el proceso social de la innovación en su carácter decolonial, ontológico y territorial, como una apuesta para redefinir el buen vivir, los proyectos de vida territoriales y las economías locales.

Palabras clave: Innovación, desarrollo, innovación social, pensamiento decolonial.

Universidad del Tolima. Ibagué-Tolima, Ingeniería Agroindustrial, Maestría en Desarrollo Rural. Colombia.

Corresponding author:jmmorenoh@ut.edu.co 


\section{Introduction}

Many are the introductory notions that can be raised in this paper. First of all, there are the different reasons that motivated writing this critique of the rural development model, confined to the transfer of technologies to increase productivity without affecting land tenure in the country. There is the duality between peasant and agroindustrial agriculture that was achieved through the imposition of a modern model based on scientific epistemology, the lack of a solution to the problems of the countryside and Colombian agriculture that are reflected in poverty and precarious rural living conditions, resulting in violence, the distribution of land, the lack of agrarian reform and the policies and interventions of the State that only respond to the interests of agribusiness companies.

This is not to mention the environmental crises generated by the separation between nature and culture, the scarcity of water, the change in traditional forms of agriculture, and rural development in purely economic terms. There is also the way in which the countries of the global south, through an alliance for a new recolonization, were imprisoned in a socalled Third World, and especially the modernizing processes of Colombian agriculture in the mid-19 $9^{\text {th }}$ century that, as expressed throughout the paper, did not take into account the problems of Colombian agriculture and rurality, but rather only sought economic growth, productivity and profitability of the systems.

As a key element to analyze this relationship between development, agriculture and modernization, innovation is one of the threads of the discussion. Through innovative elements such as agricultural machinery, technological packages, etc., rural entities make the transition to modern capitalist agriculture. Innovation can be considered as a strategy of the hegemonic discourse of development and its introduction to the economic system as a fundamental element for the growth and development of capitalism.

Nevertheless, peasant agriculture has persisted through demonstrations, struggles and resistance, contributing with essential food to the sustenance of Colombians. This allows us to glimpse a pluriverse of territories built by peasant, Afro, indigenous

\section{Introducción}

Muchas son las nociones introductorias que se pueden plantear en este artículo. En primer lugar, las diferentes razones que motivaron escribir la presente crítica al modelo de desarrollo rural, confinado en la transferencia de tecnologías para aumentar la productividad sin afectar la tenencia de la tierra en el país; la dualidad entre la agricultura campesina y agroindustrial que se logró por la imposición de un modelo moderno basado en la epistemología científica, la falta de solución a los problemas del campo y el agro colombiano que se reflejan en pobreza y precarias condiciones de vida rural, sumando las consecuencias de la violencia, la distribución de la tierra, la falta de una reforma agraria y, las políticas e intervenciones del Estado que solo responden a los intereses de las empresas agroindustriales.

Sin dejar de mencionar las crisis ambientales generadas por la separación entre naturaleza y cultura, la escasez de agua, el cambio de las formas tradicionales de la agricultura, el desarrollo rural en términos netamente económicos. La forma en que los países del sur global, por medio de una alianza para una nueva recolonización, fueron encarcelados en un denominado tercer mundo, y especialmente, los procesos modernizadores de la agricultura colombiana a mediados del siglo XIX que, como se expresa a lo largo del documento, no tomaron en cuenta los problemas de la agricultura ni de la ruralidad colombiana, solo buscaban el crecimiento económico, la productividad y la rentabilidad de los sistemas.

Como elemento clave para analizar esta relación entre desarrollo, agricultura y modernización; la innovación es una de las urdimbres de la discusión. A través de elementos innovadores como la maquinaria agrícola, los paquetes tecnológicos, etc., las ruralidades, transitan a la agricultura moderna capitalista. Se puede considerar la innovación como una estrategia del discurso hegemónico del desarrollo y su introducción al sistema económico como un elemento fundamental para el crecimiento y el desenvolvimiento del capitalismo.

No obstante, la agricultura campesina ha persistido por medio de manifestaciones, luchas y resistencias, contribuyendo con los alimentos 
and other communities, which are not reproduced in capitalist logic, even though they have a relationship with the market. This paper focuses on redefining the ways of being, doing and knowing of the communities, from a decolonial commitment and the social construction of a new innovation that considers local knowledge, techniques and technologies and directs them to redefine the wellbeing, life projects, territories, local economies and the transition towards more sustainable futures; social innovation is positioned as an ontological and counter-hegemonic action that is so characterized because communities design a technical or technological solution and also a social practice of it (Córdoba, Villamarín, \& Bonilla, 2014; Escobar, 2016; Heidegger, 1997; Manzini, 2015; Brown \& Wyatt, 2010).

The decolonial perspective constitutes an epistemic, theoretical and methodological proposal conceived as another paradigm, which questions Western/modern reasoning, as well as modern and contemporary social theories, making visible the socioeconomic and cultural realities and the reproduction of the coloniality of knowledge. It questions the use of methods and categories of European-Western scientific reasoning, which ignore, make invisible and subalternalize other epistemes or other modes of knowledge and meaning existing in the Latin American pluriverses.

In that order of ideas, this paper articulates a decolonial interpretative framework to generate understanding about the relationships between social innovation and design concepts from an ontological and territorial perspective, which has allowed Colombian peasant communities to persist in spite of the imposition of the homogenizing and colonizing model. It weaves together the autonomy of peasant communities to innovate socially and design their territories, co-constructing their happiness, their ways of life and good living.

\section{Innovation: a strategy of the hegemonic discourse of development}

In the $20^{\text {th }}$ century, one of the first authors to relate innovation to the dynamics of the functioning of the capitalist economic system and technological systems was the Austrian economist Schumpeter, who, in his book Capitalism, Socialism and esenciales en el sustento de los colombianos. Esto permite vislumbrar un pluriverso de territorios construidos por las comunidades campesinas, afro, indígenas y demás, que no se reproducen en las lógicas capitalistas, aunque tengan una relación con el mercado. La discusión de este artículo, se centra en la resignificación de los modos de ser, hacer y conocer de las comunidades, desde una apuesta decolonial y la construcción social de una nueva innovación que considere a los saberes, técnicas, tecnologías locales y los encamine a redefinir el bienestar, los proyectos de vida, territorios, economías locales y la transición hacia futuros más sustentables; posicionando la innovación social como una acción ontológica y contrahegemónica que se caracteriza porque las comunidades diseñan una solución técnica o tecnológica y también una práctica social del mismo (Córdoba, Villamarín, \& Bonilla, 2014; Escobar, 2016; Heidegger, 1997; Manzini, 2015; Brown \& Wyatt, 2010).

La perspectiva decolonial constituye una propuesta epistémica, teórica y metodológica concebida como otro paradigma, que pone en cuestión el racionamiento occidental/moderno, las teorías sociales modernas y contemporáneas. Visibilizando las realidades socioeconómicas y culturales y la reproducción de la colonialidad del conocimiento. Cuestiona el uso de métodos y categorías del razonamiento científico europeo-occidental, los cuales ignoran e invisibilizan y subalternalizan otras epistemes $u$ otros modos de conocimiento y significación existentes en los pluriversos latinoamericanos.

En ese orden de ideas, el presente documento articula un marco interpretativo decolonial para generar comprensión sobre las relaciones entre la innovación social y los conceptos de diseño desde una perspectiva ontológica y territorial, que les ha permitido a las comunidades campesinas colombianas persistir a pesar de la imposición del modelo homogenizador y colonizador. Tiene como urdimbre la autonomía de las comunidades campesinas para innovar socialmente y diseñar sus territorios, co-construyendo su felicidad, sus modos de vida y el buen vivir.

\section{La innovación: una estrategia del discurso hegemónico del desarrollo}

En el siglo XX, uno de los primeros autores en relacionar la innovación con la dinámica del 
Democracy, suggests that "capitalist dynamics is a process of industrial mutation that incessantly revolutionizes the economic structure from within, incessantly destroying the old one, incessantly creating a new one" (Shumpeter, 1942). This need to constantly create combinations of new products and technologies, to 'destroy' old products and technologies, was called 'innovation' and was forged from 'creative destruction' as the essential fact of capitalism for the unfolding of development and economic growth (Córdoba, et al., 2014; Yoguel, Barletta, \& Pereira, 2013).

'Creative destruction' is the process taken by Schumpeter from Sombart and, in particular, from Nietzsche's "will to power," for whom creativity is a function of the will to power. It is represented in the figures of the "noble" who moves to create by his will and 'the good and the just' who lack the ability to create and consequently have a great interest in maintaining the existing order (Reinert \& Reinert, 2006). Schumpeter finds relevant in Zaratustra the tension between creating and destroying as a strategy to maintain an imbalance in the market, which is solved by technological innovation to meet the demands in the evolution of the market, as well as an increase in productivity and in added value.

These innovation assumptions made it possible to position it as a fundamental force for the economic development expansion project. Innovating became a motivating force for accelerating the pace of technical and technological change in underdeveloped countries, as an exercise in domination of industrialized nations over the Third World. Moreover, in the economic development project based on the "modernization" of countries that were categorized in Truman's speech as "underdeveloped" or economically less advanced, creative destruction through technological innovations became the colonizing activity of the praxis of development (García, 1992).

In this regard, one may ask this: what did modernization represent in underdeveloped countries? As is known, modernization focused on the rationality and universality of scientific knowledge; the French sociologist Baudrillard (1979) observes, as quoted in Ferradanes (2003), that the modern is opposed to the traditional, that funcionamiento del sistema económico capitalista y los sistemas tecnológicos, fue el economista austriaco Schumpeter, quien, en su libro Capitalism, Socialism y Democracy, sugiere que, "la dinámica capitalista es un proceso de mutación industrial que revoluciona incesantemente la estructura económica desde adentro, destruyendo ininterrumpidamente lo antiguo y creando elementos nuevos" (Shumpeter, 1942). Esta necesidad de crear constantemente combinaciones de nuevos productos y tecnologías, para 'destruir' productos y tecnologías viejas, se denominó 'innovación' y fue forjada a partir de la 'destrucción creativa' como el hecho esencial del capitalismo para el desenvolvimiento del desarrollo y crecimiento económico (Córdoba, et al., 2014; Yoguel, Barletta, \& Pereira, 2013).

La 'destrucción creativa', es el proceso tomado por Schumpeter de Sombart y, en especial, de la "voluntad de poder" de Nietzsche, para quien la creatividad es una función de la voluntad de poder. Representado en las figuras del "noble" que se mueve para crear por su voluntad y 'el bueno y el justo' que carecen de la capacidad de crear, y en consecuencia, tienen un gran interés en mantener el orden existente (Reinert \& Reinert, 2006). Schumpeter encuentra pertinente en Zaratustra, la tensión entre crear y destruir como una estrategia para mantener un desequilibrio en el mercado, que se soluciona a partir de la innovación tecnológica para cumplir las exigencias en la evolución del mercado, un aumento en la productividad y en la plusvalía.

Estos supuestos de la innovación permitieron posicionarla como una fuerza fundamental para el proyecto de expansión del desarrollo económico. Innovar se convirtió en una fuerza motivadora de la aceleración del ritmo de cambio técnico y tecnológico en los países subdesarrollados, como un ejercicio de dominación de las naciones industrializadas sobre el Tercer Mundo. Más aún, en el proyecto de desarrollo económico basado en la 'modernización' de los países que, en el discurso de Truman fueron categorizados como 'subdesarrollados' o económicamente menos avanzados, la destrucción creativa a través de las innovaciones tecnológicas se convirtió en la actividad colonizadora de la praxis del desarrollo (García, 1992). 
is, the modern accepts neither previous cultures nor the geographical and symbolic diversity of traditional cultures; therefore, it imposes a radiated homogeneity from Eurocentrism. This paradigm, to which the Third World was subjected, consisted of the idea of scientific revolution as a radical break with all traditional knowledge and epistemes. In this regard, Santos (2011), who critiques this social phenomenon experienced in southern countries, states that traditional knowledge in modernization was sent to an abysmal and invisible line, derived from the hegemonic system that led to a monoculture of knowledge and scientific rigor.

Similarly, development in Latin America represented a shift in institutions and the entire institutional apparatus was transformed to achieve 'economic growth' through structural reforms, plans, programs and public policies (Hissong, 2000). And in that direction, the institution directed technological innovation through technology transfer as a strategy to industrialize and increase the productivity of economic systems in 'backward' countries. Thus, the development discourse proposed to achieve "the characteristic features of the advanced societies of the time: high levels of industrialization and urbanization, technification of agriculture, rapid growth of material production and living standards, and widespread adoption of education and modern cultural values" (Escobar, 1998).

Therefore, the scientific break with the traditional past, in the context where scientific progress was seen as social welfare, contributed to the creation of social and cultural orders (López, 1999). This converged with the fact that innovation and the transfer of technologies in productive systems also led to sign transfers, that is, cultural patterns that were necessary to adapt society to the proposed modern and technological system (Ramirez, 2013; Reyes, 2016).

However, this process, based on inequality, domination and the new colonization legitimized by 'absences' and Eurocentric reason, caused, among other things, some consequences such as: the separation of nature-culture and mind-body, the subject-object duality, the linear transformation of time and space, the marginalization of the ways of being, doing and knowing of peasant, black and
Al respecto, cabe preguntarse ¿qué representaba la modernización en los países subdesarrollados? Como es sabido, la modernización se centró en la racionalidad y universalidad del conocimiento científico, el sociólogo francés Baudrillard (1979) expresa como se cita en Ferradanes (2003) que lo moderno se opone a lo tradicional, es decir, lo moderno no acepta las culturas anteriores, ni la diversidad geográfica y simbólica de las culturas tradicionales; por lo tanto, impone una homogeneidad irradiada a partir del eurocentrismo. Este paradigma al que fue sometido el Tercer Mundo, consistió en la idea de revolución científica como una quiebra radical con todos los conocimientos y las epistemes tradicionales. Al respecto, Santos (2011) quien plantea una crítica a este fenómeno social vivido en los países del sur, expresa que los conocimientos tradicionales en la modernización fueron enviados a una línea abismal e invisible, derivada por el sistema hegemónico que conllevó a una monocultura del saber y del rigor científico.

Del mismo modo, el desarrollo en América Latina representó un cambio en las instituciones y todo el aparato institucional se transformó para alcanzar el 'crecimiento económico' a través de reformas estructurales, planes, programas y políticas públicas (Hissong, 2000). Y en esa dirección, la institución encaminó la innovación tecnológica a través de la transferencia de tecnologías, como una estrategia para industrializar y aumentar la productividad de los sistemas económicos en los países 'atrasados'. Así, el discurso del desarrollo proponía alcanzar "los rasgos característicos de las sociedades avanzadas de la época: altos niveles de industrialización y urbanización, tecnificación de la agricultura, rápido crecimiento de la producción material y los niveles de vida, y adopción generalizada de la educación y los valores culturales modernos" (Escobar, 1998).

Por ende, la ruptura científica con el pasado tradicional, en el contexto donde el progreso científico era visto como bienestar social, contribuyó a la creación de órdenes sociales y culturales (López, 1999). Esto convergió con el hecho de que la innovación y la transferencia de tecnologías en los sistemas productivos, también provocaron traspasos de signos, es decir, patrones culturales que eran necesarios para adaptar a la sociedad al sistema moderno y tecnológico propuesto (Ramirez, 2013; Reyes, 2016). 
Razial ${ }^{1}$ communities, and finally the negotiation of daily life, that is, life itself expressed in economic terms. This indisputably meant a shift in values in southern societies that currently represent environmental, social, cultural, economic and productive crises (Corredor, 1992; Escobar, 2004; Giddens, Bauman, Luhmann, \& Beck, 1996; Marín \& Morales, 2010).

\section{Effects of modernization in the Colombian countryside}

The Colombian countryside was no exception in the development and modernization processes proposed by the Eurocentric hegemonic model of knowledge, capital and power. In Colombia, with the aim of increasing agricultural supply (without affecting the structure of land tenure, which to date is considered one of the country's most significant agrarian problems), the modernization of agriculture was proposed based on rural development policies confined to technology transfer, innovation, growth and productivity. These parameters were achieved by replacing traditional and local techniques with modern technologies, improving access to credits, increasing technological packages, agricultural machinery, the 'green revolution' and, on the other hand, generating a proletarianization of rural work, the commodification of ways of life and the path of economic development to achieve rural welfare (Marín, Casamitjana, \& Loaiza, 2016; Vergara, 2011).

However, the technologies that were transferred for the modernization of Colombian agriculture were based on means of production and combinations of resources in response to specific problems in industrialized countries, which, according to Balcazar (1986), were very different from the problems presented in underdeveloped or backward countries. This commitment generated a negative effect on Colombian agriculture and a model dependent on technological development, which not only strategically limited the growth possibilities of the agricultural sector by being limited to the countries where the technology is produced, but also introduced restrictions on the dynamics of the national economic system.

'It refers to the original ancestral people and their descendants from the Archipelago of San Andrés, Providencia and Santa Catalina, Colombia.
Sin embargo, este proceso basado en la desigualdad, la dominación y la nueva colonización legitimada por las 'ausencias'y la razón eurocentrista, ocasionó entre otras, algunas consecuencias como: la separación de naturaleza-cultura y mentecuerpo, la dualidad sujeto-objeto, la transformación lineal del tiempo y el espacio, la marginación de los modos de ser, hacer y conocer de las comunidades campesinas, negras y raizales', y finalmente la negociación de la vida cotidiana, es decir, la vida misma expresada en términos económicos. Lo anterior indiscutiblemente, significó un cambio de valores en las sociedades del sur que en la actualidad representan crisis ambientales, sociales, culturales, económicas y productivas (Corredor, 1992; Escobar, 2004; Giddens, Bauman, Luhmann, \& Beck, 1996; Marín \& Morales, 2010).

\section{Efectos de la modernización en el campo colombiano}

El campo colombiano no fue la excepción en los procesos de desarrollo y de modernización propuestos desde el modelo hegemónico eurocentrista de conocimiento, capital y poder. En Colombia, con el objetivo de incrementar la oferta agrícola (sin afectar la estructura de la tenencia de la tierra, que hasta hoy es considerado uno de los problemas agrarios más importantes del país) la modernización de la agricultura se propuso a partir de políticas de desarrollo rural confinadas a la transferencia de tecnologías, la innovación, el crecimiento y la productividad. Parámetros que se lograban reemplazando las técnicas tradicionales y locales por tecnologías modernas, incrementando el acceso a créditos, aumentando los paquetes tecnológicos, la maquinaria agrícola, la 'revolución verde'y, por otro lado, generando una proletarización del trabajo rural, la mercantilización de los modos de vida y la vía del desarrollo económico para alcanzar el bienestar rural (Marín, Casamitjana, \& Loaiza, 2016; Vergara, 2011).

No obstante, las tecnologías que se transfirieron para la modernización de la agricultura colombiana se basaban en medios de producción

'Se refiere al pueblo ancestral originario y sus descendientes del Archipiélago de San Andrés, Providencia y Santa Catalina, Colombia. 
Between the 1940s and 1950s, the conditions described gave rise to a type of development characterized by the formation of two sectors clearly differentiated by their technical and economic conditions of progress: the capitalist agricultural sector, focused on crops compatible with the adopted mechanization patterns (cereals, oilseeds, potatoes, soybeans, sugarcane, cotton, etc.) and the peasant agricultural sector, focused on crops discriminated against by the mechanization process (cassava, bananas, fruits and vegetables) (Balcazar, 1986).

Consequently, innovation and the transfer of technologies used as a mechanistic strategy in spreading modern ideals to the global south increased the duality between peasant and capitalist agriculture. And as expected, this duality represented a directing of state policies on infrastructure, land, capital and machinery towards agricultural entrepreneurs, which was decisive for the success of agro-industrial enterprises over peasant agriculture (Kay, 2007).

Bejarano (1983), Machado (1999) and Fajardo (2002), among others, offer a critique of the logic of rural development and the modernization of agriculture, since it did not respond to the need for the sustainability of Colombian agriculture. Moreover, it did not alleviate 'rural poverty' or solve the problems of agrarian conflict, exclusion, inequality, productivity, excessive land concentration, and social injustice; nor has it promoted the dignification of rural life. On the contrary, it favored a nascent agro-industry that displaced and marginalized peasant agriculture, as well as stripped peasants of their land.

Peasant agriculture, despite its abandonment by institutions and the State, has persisted and contributes with a little more than half of agricultural production, with about $80 \%$ of coffee production and a third of the value of livestock production (Acevedo, Garavito, Salgado, \& Gallego, 2015; Forero, 2003; Forero \& Garay, 2013; Santacoloma, 2015). In this regard, it is essential to ask: How and why have peasant communities persisted despite the imposition of the modernizing model? And to recognize and visualize how the communities of the y combinaciones de recursos en respuesta a problemas específicos en los países industrializados, los cuales, de acuerdo con Balcazar (1986), eran muy distintos a los problemas presentados en los países subdesarrollados o atrasados. Tal apuesta generó un efecto negativo en la agricultura colombiana y un modelo dependiente del desarrollo tecnológico, que no solo limitó estratégicamente las posibilidades de crecimiento del sector agropecuario al quedar limitadas a los países donde se produce la tecnología, sino que introdujo restricciones en la dinámica del sistema económico nacional.

Entre los años 40 y 50 las condiciones descritas dieron origen a un tipo de desarrollo caracterizado por la conformación de dos sectores claramente diferenciados por sus condiciones técnicas y económicas de progreso: el sector capitalista de la agricultura, concentrados en cultivos compatibles con los patrones de mecanización adoptados (cereales, oleaginosas, papa, soya, caña de azúcar, algodón, otros) y el sector de la agricultura campesina que se concentra en los cultivos discriminados por el proceso de mecanización (yuca, plátano, frutas y hortalizas) (Balcazar, 1986).

En consecuencia, la innovación y la transferencia de tecnologías utilizadas como una estrategia mecanicista en la extensión de los ideales modernos al sur global, aumentó la dualidad entre agricultura campesina y capitalista. Y como era de esperarse, dicha dualidad representó un direccionamiento de las políticas de estado en infraestructura, tierras, capital y maquinaria hacia los empresarios agrícolas, lo cual fue determinante para el éxito de las empresas agroindustriales sobre la agricultura campesina (Kay, 2007).

En Bejarano (1983), Machado, (1999) y Fajardo (2002), entre otros, se vislumbra una crítica sobre la lógica del desarrollo rural y la modernización de la agricultura, ya que no respondió a la sustentabilidad del agro colombiano el alivio a la 'pobreza rural', la solución del conflicto agrario, la exclusión, la inequidad, la productividad, la pobreza rural, la desigualdad, la excesiva concentración de la tierra, la injusticia social, ni la dignificación de la vida rural, sino por el contrario, favoreció a una naciente agroindustria que desplazaba, marginaba y despojaba de tierras a la agricultura campesina. 
Colombian Andes, with their communal dynamics, heterogeneities, persistence of family work relationships and rejection of modernization, have managed to position themselves as an alternative form of rurality, which goes beyond the limits of the capitalist accumulation system. The knowledge, wisdom and practices of the rural communities, such as those of the indigenous, Afro, Raizal, peasant and other groups, undoubtedly respond to the logic of life from the communal aspect with cultural, productive and technical practices, as well as creativity and knowledge (Quintero, 2011).

Nevertheless, and in the critical direction towards the development model based on the linear transfer of technologies from the Eurocentric scientific rationality, which undermines the autonomy and creativity of the communities, this paper redefines the techniques and technologies that the communities design, which, for the most part, are also inherent to the configuration of the territories. Signs, values and ways of doing of each community are deposited in these techniques and technologies in order to respond to local needs and issues, which definitely diverge from the technology imposed by the innovative model.

\section{Technique and technology as territorial configurators}

Giving continuity to the approach in which communities design, with creativity, techniques and technologies to respond to local needs and issues, an approach is first made to the historical geography of technique and technology to understand their importance in rural communities. In Heidegger, technique is based on two dimensions: as an object in the hand (instrument) and as an imperative or structure of action in the world. Thus, the Heideggerian question about technique was distinguished between technique as an object (artifacts and technical systems) that also corresponds to the needs and purposes it serves, and the essence of the technique, which cannot be confused with anything technical (Linares, 2003). These distinctions in Heidegger enable us to understand that technique is inherent in human action and is related to the needs in the environment in which it is generated; therefore, it should not be
La agricultura campesina a pesar del abandono de la institucionalidad y el Estado, ha persistido y contribuye con un poco más de la mitad de la producción agrícola, con cerca del $80 \%$ de la producción cafetera y con una tercera parte del valor de la producción pecuaria (Acevedo, Garavito, Salgado, \& Gallego, 2015; Forero, 2003; Forero \& Garay, 2013; Santacoloma, 2015). En ese sentido, es fundamental preguntarse ¿Cómo y porqué las comunidades campesinas han persistido a pesar de la imposición del modelo modernizador? Y reconocer y vislumbrar a las comunidades de los andes colombianos que, con sus dinámicas comunales, heterogeneidades, persistencia de las relaciones de trabajo familiar y rechazo por la modernización, han logrado posicionarse como una forma alternativa de ruralidad, que se desborda de los límites del sistema de acumulación capitalista. De tal manera que los conocimientos, saberes y prácticas de las comunidades rurales, como son las indígenas, afro, raizales, campesinas y demás, que sin lugar a dudas, responden a lógicas de vida desde lo comunal con prácticas culturales, productivas, técnicas, creatividad y saber (Quintero, 2011).

No obstante, y en la dirección crítica hacia el modelo de desarrollo basado en la transferencia lineal de tecnologías desde la racionalidad científica eurocéntrica, que atenta contra la autonomía y la creatividad de las comunidades, en este artículo se resignifican las técnicas y tecnologías que las comunidades diseñan, las cuales, en su mayoría, son inherentes también a la configuración de los territorios. En ellas se depositan signos, valores y formas de hacer de cada comunidad para responder a las necesidades y emergencias locales, que definitivamente, divergen con la tecnología impuesta por el modelo innovador.

\section{La técnica y la tecnología como configuradores territoriales}

Dando continuidad al planteamiento en que las comunidades diseñan con creatividad, técnicas y tecnologías para responder a las necesidades y emergencias locales, inicialmente se hace un acercamiento a la geografía historizada de la técnica y la tecnología para comprender su importancia en las comunidades rurales. En Heidegger, la técnica 
answered from universal rationality, much less in the transfer of modern techniques that it brings hidden with it the imperative of accumulation and exploitation of nature.

On the other hand, epistemological and philosophical studies define technology as a social construction with components aimed at solving complex problems, involving technique (artefacts, instruments), knowledge (traditional and practical) and social structure (Tabares \& Correa, 2014). Marx identified technique and technology as the engine of human emancipation in his theory of historical development, according to which the development of the means of production, determined by technical innovations, is what shapes the changes in sociopolitical and ideological structures. It can be said, then, that the resolution of problems by inventions and technical instruments allowed the evolution of technology as a natural extension of man (Marx, 1867).

However, while a much broader theoretical approach is required to understand the historical relationship of technique and technology in shaping humanity's sociopolitical structures, this approach attempts to make clear that both technique and technologies are constructions and designs that respond to people's daily needs and are therefore part of the territorial configuration of communities. This ratifies that the problems of rurality can only be solved in and by the communities, and not by an imposed economic model, which for the sake of productivity has exacerbated the realities of the countryside.

In this respect, the proposal from southern thinking, the other epistemes and the decolonization of being and knowing are a theoretical basis for considering local, ancestral and traditional knowledge, wisdom, techniques and technologies as essential in territorial life projects. And on this path the proposal of innovation from a social fabric also arises, an innovation that allows the participatory action of the community to provide solutions to technological, economic and social issues present in the territory. The other innovation arises from social movements, self-organizing processes and spaces for the reorientation of development, which invites us to think that 'because of its social character' it can be considered as an alternative to hegemonizing development. se funda en dos dimensiones: como objeto a la mano (instrumento) y como imperativo o estructura de acción en el mundo. Así pues, la pregunta heideggeriana por la técnica, se distinguió entre la técnica como objeto (artefactos y sistemas técnicos) que corresponde también a las necesidades y a los fines a los que sirven; y la esencia de la técnica, que no puede confundirse con nada técnico (Linares, 2003). Estas distinciones en Heidegger permiten comprender que la técnica es inherente al actuar humano y se relaciona con sus necesidades en el entorno en que se generan, por tanto, no debe responderse desde la racionalidad universal, ni mucho menos en la transferencia de las técnicas modernas que trae oculto consigo el imperativo de acumulación y explotación de la naturaleza.

Por otro lado, los estudios epistemológicos y filosóficos definen a la tecnología como una construcción social con componentes destinados a la resolución de problemas complejos, involucrando a la técnica (artefactos, instrumentos), a los saberes (conocimientos tradicionales y prácticos) y a la estructura social (Tabares \& Correa, 2014). Marx emplazó la técnica y la tecnología como motor de la emancipación humana en su teoría del desarrollo histórico y según esta teoría, el desarrollo de los medios de producción, determinado por las innovaciones técnicas, es el que configura los cambios en las estructuras socio-políticas e ideológicas. Se puede decir entonces, que la resolución de problemas a partir de las invenciones e instrumentos técnicos, permitió la evolución de la tecnología como una extensión natural del hombre (Marx, 1867).

Sin embargo, si bien se requiere de un abordaje teórico mucho más amplio para comprender la relación histórica de técnica y tecnología en la configuración de las estructuras socio-políticas de la humanidad, lo que se pretende con este acercamiento es dejar claro que tanto la técnica como las tecnologías son construcciones y diseños que responden a las necesidades en la cotidianidad de las personas, $y$, por tanto, hacen parte de la configuración territorial de las comunidades. Con esto, se ratifica que los problemas de la ruralidad solo pueden ser solucionados, en y desde las comunidades, y no desde un modelo económico impuesto, que en aras de la productividad ha agudizado las realidades del campo. 


\section{The other innovation: From a social fabric}

Reference should be made to the actions of the Earth's feeling-thinking people that have envisioned. from struggles, mobilizations and resistance movements, processes to liberate and mend not only the relationships between human beings but also the interrelationships with nature, rectifying their political position in the design of their ways of being-doing and knowing, and their work relationships rooted in traditional, cultural and ancestral practices. This way of redefining peasant communities is based on the decolonial fact. Epistemic decolonization is the openness to the plural, to the richness of difference; it is proposed as a possibility of horizontalizing societies from knowledge and practices, not to be included in the hegemonic model but to intervene in it, question it, and subvert it, inventing new alternatives that escape and impact the pre-established order; opening pluriversalities as an option to modern rational universality (Jaramillo, 2013).

Given this panorama of visualizing the experiences of communities, design has become a tool for horizontality, as can be seen in Escobar (2016), when a pluriverse of possibilities is interwoven according to the framework of the design's potentialities. This author argues that autonomous design and design for transitions are challenging spaces for reorienting development, using the creativity of all actors for transitions towards more sustainable futures and to deal with problems such as the physical, social and cultural quality of the places, and the physical, social and cultural quality of the planet as a whole.

At this point it is also necessary to take up again the historical fabric regarding the forms of innovation, since in decolonial actions, social learning of innovation is considered as a convergence space for design, participation and creativity in the service of wellbeing, the quality of life of rural communities and the alternatives to continue generating solutions in rurality. Now, how is social innovation conceived?

Manzini $(2015)^{2}$ states that in the phenomenon of design and co-creation, where different individuals and communities interact, a process of social

${ }^{2}$ Book "Design, When Everybody Designs: An Introduction to Design for Social Innovation". Diseño donde todos diseñan: Una introducción al diseño para la innovación social.
Al respecto, la propuesta desde el pensamiento del sur, las otras epistemes y la descolonización del ser y el saber, son un fundamento teórico para considerar los saberes, conocimientos, técnicas y tecnologías locales, ancestrales y tradicionales, como esenciales en los proyectos de vida territorial. $Y$ en ese camino también surge la propuesta de la innovación desde un tejido social, una innovación que permite la acción participativa de la comunidad para dar soluciones a emergencias tecnológicas, económicas y sociales presentes en el territorio. La otra innovación surge de movimientos sociales, procesos autoorganizativos y espacios para la reorientación del desarrollo, que invita a pensar que 'por su carácter social' se puede considerar como una alternativa al desarrollo hegemonizador.

\section{La otra innovación: Desde un tejido social}

Conviene hacer referencia a las acciones de los sentipensantes de la tierra que han vislumbrado a partir de luchas, movilizaciones y resistencias, procesos para liberar y recomponer no solo las relaciones entre los seres humanos sino también las interrelaciones con la naturaleza, rectificando su posición política en el diseño de sus formas de ser-hacer y conocer, y sus relaciones de trabajo arraigadas en las prácticas tradicionales, culturales y ancestrales. Esta forma de resignificar a las comunidades campesinas se respalda en el hecho decolonial. La descolonización epistémica es la apertura a lo plural, a la riqueza de la diferencia, se plantea como una posibilidad de horizontalizar las sociedades desde el conocimiento y las prácticas, no para ser incluidos en el modelo hegemónico sino para intervenir en él, cuestionarlo, subvertirlo, inventando nuevas alternativas que se escapen e impacten el orden preestablecido; abriendo pluriversalidades como opción a la universalidad racional moderna (Jaramillo, 2013).

Ante este panorama de visualización de las experiencias de las comunidades, el diseño se ha convertido en una herramienta para la horizontalidad, como puede verse en Escobar (2016), cuando se entrelaza un pluriverso de posibilidades de acuerdo al marco de las potencialidades del diseño. Este autor, plantea que el diseño autónomo y el diseño para las transiciones son espacios de 
learning of innovation occurs by creating 'bridges,' by generating new solutions, technologies and products/services. This is the active principle of social innovation, the construction of solutions where everyone aims to enhance the well-being and quality of the places, processes, products and services of the area in which they live (Manzini, 2009).

Therefore, social innovation is a complex and multidimensional phenomenon that has gone in a short time from being emergent and marginal to occupying a relevant position in the social-political discourse. Moreover, this leading role has been nurtured thanks to contributions made by different disciplines in the academic world and, on the other hand, an endless number of innovative practices of various kinds, such as social entrepreneurships, corporate social responsibility, open innovation, crowdsourcing and collaborative economics, among others, have emerged as a result of the creativity and impetus of different social movements and groups (Abreu, 2011).

It is so characterized because it does not produce only in the technical artifact, but is also a social practice of it, as previously stated in the Heideggerian perspective. That is, it is assumed that innovation is no longer focused on the processes but on the actors who benefit or are harmed by this change. From this perspective, we are dealing with two interrelated dimensions, since technological developments are caused by social needs and at the same time social difficulties lead to technological and objective inventiveness for their solution (Córdoba, et al., 2014).

The renewing nature of social innovation experiences departs from the typical versions of innovation (Morales, 2014). The novelty in this type of innovation is not measured as strictly as in the case of technological innovations, or in social experiences, but rather depends on small adaptations to solutions that have not been applied in specific contexts. While it is true that all innovations are related to society because it is people who create them and it is the same people who accept them and, therefore, allow them to intervene in their lifestyles, the social aspect of this type of innovation is determined in another sense because, first of all, in these experiences the social aspect implies a consideration that goes desafío para reorientar el desarrollo, utilizando la creatividad de todos los actores para transiciones hacia futuros más sustentables $y$, para hacer frente a problemas como la calidad física, social y cultural de los lugares, y la calidad física, social y cultural del planeta como un todo.

También, en este punto es necesario retomar el tejido histórico sobre las formas de la innovación, pues en las acciones decoloniales, el aprendizaje social de la innovación se considera como un espacio de convergencia para el diseño, la participación y la creatividad al servicio del bienestar, la calidad de vida de las comunidades rurales y las alternativas para continuar generando soluciones en la ruralidad. Ahora bien, ¿Cómo se concibe la innovación social?

Manzini $(2015)^{2}$ expone que en el fenómeno de diseño y co-creación, donde diferentes individuos y comunidades interactúan, se presenta un proceso de aprendizaje social de la innovación al crear 'puentes', al generar nuevas soluciones, tecnologías y productos/ servicios. Este es el principio activo de la innovación social, la construcción de soluciones donde todos hacen presencia para apuntar al bienestar y la calidad de los lugares, procesos, productos y servicios en que se habita (Manzini, 2009).

Por tanto, la innovación social es un fenómeno complejo y multidimensional que ha pasado en poco tiempo de ser emergente y marginal a ocupar una posición relevante en el discurso político-social. Más, ocurre que este papel protagonista se ha alimentado gracias a las aportaciones realizadas desde diferentes disciplinas del mundo académico y por otro, han proliferado un sinfín de prácticas innovadoras de diversa índole -emprendimientos sociales, responsabilidad social corporativa, open innovation, crowdsourcing, economía colaborativa, etcétera- que emergen desde la creatividad y el impulso de distintos movimientos y grupos sociales (Abreu, 2011).

Se caracteriza porque no produce solamente en el artefacto técnico, sino que es una práctica social del mismo, como se enunció anteriormente en la perspectiva heideggeriana. Es decir, se asume que la innovación ya no se centra en los procesos sino en los

${ }^{2}$ Libro "Design, When Everybody Designs: An Introduction to Design for Social Innovation". Diseño donde todos diseñan: Una introducción al diseño para la innovación social. 
beyond the market or profit-making (HernándezAscanio, Tirado-Valencia, \& Ariza-Montes, 2016).

In this case, the social aspect focuses on the mobilizations, struggles and resistance movements of groups that have been made invisible and that have designed, via social innovation, solutions to improve their living conditions. Secondly, innovations are social both in their ends and in their means; therefore, the process of a social innovation must be participatory, inclusive and have no negative effects on other social groups or on the environment. Likewise, the value generated in this process should not be accumulated by a few, but should be extended to society as a whole (Castillo, 2014).

\section{By way of reflection}

These annotations allow us consider that social innovation is complemented by design, since in its essence it allows visualizing a pluriverse of alternatives to achieve the well-being of rural communities, building places for transitions, valuing the techniques and technologies with which communities have addressed their issues and enabling a way of being, doing and knowing, where difference is respected and local, ancestral and traditional knowledge is recognized as a source of hope for rurality, as proposed in the epistemology of the south and the decolonization of knowledge. All of the factors above, together with territorial dynamics, allow communities to be positioned as actors and managers of their rurality. Actions, therefore, are needed that are channeled in that direction and towards the participatory construction of the territory and good living.

End of English version

\section{References / Referencias}

Abreu, L. (2011). Social Innovation: Concepts and Stages. International Journal of Good Conscience, vol. 6, núm. 2, pp. 134-148.

Acevedo, Á. Garavito, L., Salgado, D., \& Gallego, J. (2015). Contribuciones de la agricultura familiar en Colombia desde el enfoque de la multifuncionalidad. Tres estudios de caso de agricultura familiar. Documentos de trabajo, vol. 1, pp. 5 - 38 actores que se benefician o se ven perjudicados por este cambio. Desde esta perspectiva, se trata de dos dimensiones interrelacionadas, pues los desarrollos tecnológicos son originados por necesidades sociales y a su vez las dificultades sociales propician inventivas tecnológicas y objetivas para su solución (Córdoba, et al., 2014).

El carácter renovador de las experiencias de innovación social se aleja de las versiones típicas de la innovación (Morales, 2014). Lo novedoso en este tipo de innovación no se mide de una forma tan estricta como con las innovaciones tecnológicas, o en las experiencias sociales, esta depende de pequeñas adaptaciones a soluciones que no se hayan aplicado en contextos determinados. Si bien es cierto que todas las innovaciones tienen relación con la sociedad porque son las personas quienes las crean y son las mismas personas quienes las aceptan $y$, por lo tanto, permiten que éstas intervengan en sus estilos de vida, lo social de este tipo de innovación es determinado en otro sentido porque en primer lugar, en estas experiencias lo social implica una consideración que va más allá del mercado o de la obtención de lucro (Hernández-Ascanio, TiradoValencia, \& Ariza-Montes, 2016).

En este caso lo social se centra en las movilizaciones, luchas y resistencias de los grupos que han sido invisibilizados y que han diseñado en la innovación social soluciones para mejorar sus condiciones de vida. En segundo lugar, las innovaciones son sociales tanto en sus fines como en sus medios; por lo tanto, el proceso de una innovación social debe ser participativo, inclusivo $y$ no tener efectos negativos sobre otros grupos sociales o sobre el medio ambiente. Asimismo, el valor que se genere en este proceso no debe ser acumulado por unos pocos, sino que debe ser extensivo a la sociedad (Castillo, 2014).

\section{A manera de reflexión}

De estas anotaciones se permite considerar que la innovación social se complementa con el diseño, pues en su esencia permite visualizar un pluriverso de alternativas para alcanzar el bienestar de las comunidades rurales, construyendo lugares para las transiciones, valorando las técnicas y tecnologías con las que las comunidades han dado solución a sus 
Bálcazar, A. (1986). Cambio técnico en la agricultura. En Problemas agrarios colombianos. Bogotá. Siglo Veintiuno.

Baudrillard, J. (1979). Voz "modernité". Enciclopedia Universalis, Vol 11. París

Bejarano, J. (1983). Campesinado, Luchas Agrarias e Historia Social: Notas para un balance historiográfico. Anuario Colombiano de Historia Socialy de la Cultura, vol. 11, pp. 251-304.

Brown, T., \& Wyatt, J. (2010). Design Thinking for Social Innovation. Stanford Social Innovation Review, 7. Recuperado a partir de www.ssireview.com

Castillo, Y. (2014). Innovación social y desarrollo local. Competencias sociales para la movilización socio/ cultural y productiva de las comunidades del departamento del Cauca, Colombia. Universidad del Cauca.

Córdoba, C., Villamarín, F., \& Bonilla, H. (2014). Innovación social: Aproximación a un marco teórico desde las disciplinas creativas del diseño y las ciencias sociales. Tendencias, vol. XV, núm. 2, pp. 30-44.

Corredor, C. (1992). Los límites de la modernización. Bogotá. Universidad Nacional de Colombia.

Escobar, A. (1998). La invención del tercer mundo: Construcción y deconstrucción del desarrollo. Bogotá. Norma.

Escobar, A. (2004). Más allá del Tercer Mundo: Globalidad, imperialidad, colonialidad global y movimientos sociales anti-globalización. Nómadas, vol. 20, pp. 86-100.

Escobar, A. (2016). Autonomía y diseño: La realización de lo comunal. Popayan. Universidad del Cauca.

Fajardo, D. (2002). Para sembrar la paz, hay que aflojar la tierra: comunidades, tierras y territorios en la construcción de un país. Bogotá. Universidad Nacional de Colombia

Ferradanes, F. (2003). “El devenir de la modernidad: Crisis del paradigma y acercamiento a una nueva epistemología social". Aposta. Revista de Ciencias Sociales, vol. 1, pp 1- 35.

Forero, J. (2003). Economía campesina y sistema alimentario en Colombia: Aportes para la discusión sobre seguridad alimentaria. Bogotá. Universidad Javeriana.

Forero, J., \& Garay, L. (2013). Eficiencia económica de los grandes, medianos y pequeños productores emergencias y posibilitando un modo de ser, hacer y conocer, donde se respeta la diferencia y se reconoce el saber local, ancestral y tradicional como fuente de esperanza para la ruralidad, como se plantea en la epistemología del sur y la descolonización del saber. Todo lo anterior, sumado a las dinámicas territoriales, permiten posicionar a las comunidades como actoras y gestoras de su ruralidad y es menester develar acciones que se encaminen en esa dirección y en la construcción participativa del territorio y el

Fin de la versión en español

agricolas en Colombia. Bogotá. Universidad Javeriana.

García de la Huerta, M. (1992). La técnica y la difusión del ideal de modernidad. Estudios sobre sociedady tecnología, pp. 131-160.

Giddens, A., Bauman, Z., Luhmann, N., \& Beck, U. (1996). Las consecuencias perversas de la modernidad. Barcelona. Anthropos.

Heidegger, M. (1997). La pregunta por la técnica. Filosofía, Ciencia y Técnica. pp. 117-154.

Hernández-Ascanio, J.,Tirado-Valencia, P., \& ArizaMontes, A. (2016). El concepto de innovación social: ámbitos, definiciones y alcances teóricos. CIRIEC. vol. 88, pp. 164-199.

Hissong, R. (2000). Las teorías y las prácticas de desarrollo desde la perspectiva de la modernidad. Bogotá: Universidad de los Andes.

Jaramillo, C. (2013). Descolonizar el ser, el saber y el poder en la Universidad Latinoamericana. Medellín. Universidad San Buenaventura.

Kay, C. (2007). Pobreza rural en América Latina:Teorías y estrategias de desarrollo. Revista Mexicana de Sociología. vol 39, núm. 1, pp 69-108.

Linares, J. (2003). “La concepción heideggeriana de la técnica: Destino y peligro para el ser del hombre". Signos Filosóficos. vol 10, pp 15-44.

López, J. (1999). Los estudios de ciencia, tecnología y sociedad. Revista Iberoamericana de educación. vol 20, pp 217-225.

Machado, A. (1999). La cuestión agraria y el sector agropecuario. Cuadernos de Economía, vol. XVII, núm. 31, pp 237-279. 
Manzini, E. (2009). Viewpoint: New design knowledge. Design Studies, vol. 30, n 1, pp. 4-12.

Manzini, E. (2015). Design, when everybody designs: an introduction to design for social innovation. Cambrigde. MIT Press.

Marín, A., \& Morales, J. (2010). Modernidad y modernización en America Latina: Aventura inacabada. Nómadas. Revista Crítica de Ciencias Sociales y Jurídicas, vol. 26, núm. 2, pp. 1-20.

Marín, M., Casamitjana, M., \& Loaiza, J. (2016). Políticas de modernización agropecuaria y desarrollo rural en Colombia (1996-2008). Revista EIA, vol. 13, núm. 25, pp. 99-108.

Marx, C. (1867). El Capital. La Habana (1973). Editorial de Ciencias Sociales. Tomo I. P 287

Morales, D. (2014). "Innovación social y acción colectiva, un estudio de caso: Ecoagricultores del Sur". Estudios Políticos, vol. 33, pp 75-95.

Quintero, M. (2011). El habitar poético: Una aproximación al «Genius Loci» de la arquitectura contemporánea. Bogotá. Universidad Nacional de Colombia.

Ramirez, J. (2013). Innovación metodológica en una época e ruptura. Aportes para su comprensión. En Observar, escuchar y comprender (pp. 339-367). Ciudad de México. FLACSO.

Reinert, H., \& Reinert, E. (2006). Creative Destruction in Economics: Nietzsche, Sombart, Schumpeter.
En D. W. Backhaus JG (Ed.), Friedrich Nietzsche (1844-1900) (3. a ed., pp. 55-85). Boston. Springer

Reyes, R. (2016). Modernidad, Modernismo y Tecnología: concepciones y valoraciones. Revista Comunicación, vol. 25, núm. 37, pp. 48-56.

Santacoloma, L. (2015). Importancia de la economía campesina en los contextos contemporáneos: Una mirada al caso colombiano. Entramado, vol. $11, n^{\circ} 2$, pp. 38-50.

Santos, B. (2011). Epistemologías del Sur. Utopía y Praxis Latinoamericana, vol. 16, núm. 54, pp 17-39.

Schumpeter, J. (1942). Can capitalism survive? En Capitalism, Socialism and Democracy (pp. 59-156). London. Routledge.

Tabares, J., \& Correa, S. (2014). Tecnología y sociedad. Una aproximación a los estudios sociales de la tecnología. Revista Iberoamericana de Ciencia, Tecnología y Sociedad - CTS, vol. 9, núm. 26, pp. 129144.

Vergara, W. (2011). Desarrollo del subdesarrollo o nueva ruralidad para Colombia. Cartografías del desarrollo rural. Revista de la Universidad de la Salle, vol. 55, pp 33-66.

Yoguel, G., Barletta, F., \& Pereira, M. (2013). De Schumpeter a los postschumpeterianos: viejas y nuevas dimensiones analíticas. Revista Problemas del Desarrollo, vol. 174, núm. 44, pp. 35-59. 